\title{
One-Bank Holding Companies: The Case Against a Legislative Roadblock
}

\author{
"That is to fear which has the power to harm." \\ -DANTE, THE INFERNO
}

Holding companies controlling a single bank have existed in the United States for nearly a century. ${ }^{1}$ Until recently, such holding companies primarily controlled only the smaller banks ${ }^{2}$ and were generally organized either to provide banking services for the employees of large nonbanking corporations ${ }^{3}$ or to provide banking services in small rural communities. 4

Beginning in 1968, however, a significant number ${ }^{5}$ of the country's large commercial ${ }^{6}$ banks began to organize their own one-bank holding companies. ${ }^{7}$ These holding companies are the product of a form

1 The earliest one-bank holding company in this country appears to have been formed not later than 1880 with the establishment of the Amoskeag National Bank of Manchester, New Hampshire, as a subsidiary of the Amoskeag Savings Bank. See STAFF of House Comm. on Banking and Currency, 9lst Cong., 1st Sess., The Growth of Unregistered Bank Holding Companies-Problems and Prospects 294 (Comm. Print 1969) [hereinafter cited as STAFF REPORT].

2 Id. at 6.

3 Hearings on H.R. 2674 Before the House Comm. on Banking and Currency, 84th Cong., Ist Sess. 569 (1955). A typical example is that of the 3M Company's construction of the Eastern Heights State Bank in 1959 in order to provide banking services for its employees in a rural part of St. Paul, Minnesota. Hearings on S. 2353, S. 2418, and H.R. 7371 Before a Subcomm. of the Senate Comm. on Banking and Currency, 89th Cong., 2d Sess., pt. 1, 409 (1966) [hereinafter cited as 1966 Hearings].

4 In smaller communities a family or a group of a few business associates might own several of the local business establishments including a bank. The various firms would typically be owned by a single corporation which facilitates transfer of ownership and the raising of capital. See 1966 Hearings, supra note 3, at 119-20, 139-41.

5 By the beginning of 1969, 34 of the 100 largest commercial banks in the United States had either formed or announced their intention of forming one-bank holding companies. These banks hold deposits of over $\$ 100$ billion, about $25 \%$ of all commercial bank deposits in this country. STAFF REPORT, supra note 1, at 6-7.

6 A commercial bank's distinguishing characteristic is that it may provide checking accounts (demand deposits) for its customers, a service which may not lawfully be performed by such closely related financial institutions as savings and loan associations and mutual savings banks. In this article, the term "bank" always refers to commercial banks unless the context indicates otherwise.

7 In addition to bank-organized holding companies, it is possible for a nonbanking conglomerate to form a one-bank holding company through the acquisition of a single bank. Between Sept. 1 and Dec. 31, 1968, sixteen nonbank corporations each announced its intention of purchasing a bank and thereby becoming a one-bank holding company. 
of corporate legerdemain in which each bank eventually becomes a subsidiary of a corporation created by the bank to effect the reorganization. $^{8}$

As long as the holding company retains control of only a single bank, ${ }^{9}$ it is free to acquire an almost unlimited variety of subsidiaries. ${ }^{10}$ This ability to engage in nonbanking businesses and to escape from the myriad of regulations to which banks are subject ${ }^{11}$ has prompted the introduction in the current session of Congress of a number of bills, having as their common denominator the imposition of restraints upon the activities of one-bank holding companies. ${ }^{12}$

STAFF REPORT, supra note 1 , at 48 . Most of the factors considered by this comment apply both to bank-originated and nonbank-originated one-bank holding companies. Where differences might be present, they are noted.

8 Alternative techniques are available for accomplishing the reorganization. One method is to exchange the bank's stock on a share-for-share basis for stock in the holding company. An alternative technique is the "phantom bank" method, so named because the holding company first becomes the owner of a newly chartered but commercially inactive (i.e., a "phantom") bank and then merges the old bank into the new one. The second method is essentially a force-out merger which effectively eliminates any dissenting shareholders. See Shapiro, The One-Bank Holding Company Movement: An Overview, 86 BANKing L.J. 291, 296-7 (1969).

9 Bank holding companies controlling two or more banks are subject to the provisions of the Bank Holding Company Act of 1956, 12 U.S.C. §§ 1841-9 (Supp. IV, 1969), amending 12 U.S.C. $\$ \S 1841-8$ (1964). This Act is administered by the Board of Governors of the Federal Reserve Board, 12 U.S.C. \$ 1844 (1964), and in general prohibits a multi-bank holding company from acquiring more than a de minimus interest in nonbanking corporations, 12 U.S.C. $\$ 1843(c)(5)$ (Supp. IV, 1969), except those which are "of a financial, fiduciary, or insurance nature and which the Board ... has determined to be so closely related to the business of banking" as not to be subject to the prohibitions of the Act. 12 U.S.C. \$ 1843 (c)(8) (Supp. IV, 1969).

10 The only exception, but an important one, is that the holding company could not directly or indirectly engage "in the issue, flotation, underwriting, public sale, or distribution" of securities. See 12 U.S.C. $\$ 377$ (1964) (originally enacted as Act of June 16, 1933, ch. 89, $\S 20,49$ Stat. 704, 707), one of the many banking statutes engendered by the Great Depression.

I1 See generally Hackley, Our Baffling Banking System (pts. 1 \& 2), 52 VA. L. REv. 565, 771 (1966).

12 H.R. 946, 91st Cong., 1st Sess. (1969); H.R. 6778, 91st Cong., 1st Sess. (1969); H.R. 9385, 91st Cong., 1st Sess. (1969); H.R. 12,130, 91st Cong., 1st Sess. (1969); and S. 1664, 91st Cong., 1st Sess. (1969). The House bills have been the subject of hearings held by the House Committee on Banking and Currency. All of the proposals perform two tasks: (1) placing one-bank holding companies under the supervision of some federal administrative agency and (2) prohibiting one-bank holding companies from engaging in nonbanking businesses either directly or through subsidiaries, except under certain limited conditions. The bills are not in agreement with respect to which agency should supervise one-bank holding companies; some opt for the Federal Reserve Board of Governors alone, others prefer a system involving the Comptroller of the Currency and the Federal Deposit Insurance Corporation (FDIC) in addition to the Federal Reserve Board. Nor is there agreement with respect to the exceptions to the "nonbanking business" prohibition; some favor a specified list of exemptions while others recommend broad guidelines to be interpreted by the appropriate federal regulatory agency. A detailed examination . 
This comment advances the thesis that one-bank holding companies provide a method for improving economic efficiency in allocating resources and are therefore economically desirable. The arguments which have been put forth by those who seek to restrain the activities of one-bank holding companies are examined and found to be without substantial merit. A number of potential problems that could develop from the one-bank holding company structure are discussed; methods of dealing with them under existing laws are considered; and suggestions are made for legislative revision where such revision appears necessary.

\section{Bank Holding Companies: The Egonomic Rationale}

Several reasons have been offered to explain the current popularity among the banking community of one-bank holding companies. ${ }^{13}$ An illustrative list would include (1) the ability of the one-bank holding company to diversify into nonbanking activities thought to yield higher profits than otherwise attainable by banks; ${ }^{14}$ (2) the ability of the bank holding company to achieve greater flexibility in its capital structure through the issuance of a larger proportion of debt instruments than could be achieved under the existing climate of bank regulations; ${ }^{15}$ and (3) the ability to attract and retain talented personnel by offering remuneration in excess of that offered by a bank's typically low salary structure without the necessity to upgrade the salary scale of those employed by the bank. ${ }^{16}$

Explanation is not, however, justification. Consequently the critical question remains: Are there any benefits which the commonweal might derive by permitting the formation and unregulated operation of one-bank holding companies? To answer this question requires an examination of the role of banks in the economy.

The primary ${ }^{17}$ function of commercial banks has been to act as financial intermediaries, receiving funds from those economic units

of the provisions of these bills is beyond the scope of this comment which takes the position that legislation of this type is both unwarranted and unwise.

13 A nonbanking corporation which becomes a one-bank holding company is presumably motivated by the belief that the acquisition of the bank will be a profitable investment because of the bank's own ability to produce net income, perhaps enhanced by better management supplied by the acquiring firm.

14 See The One-Bank Holding Company: Threat or Threshold?, 78 ForTune 55 (Nov. 1968).

15 Nadler, The One-Bank Holding Company, 61 Banking 34, 35 (Dec. 1968).

16 Id. at 34.

17 Commercial banks provide a variety of money-oriented services such as the rental of safe-deposit boxes, the administration of decedents' estates, and trust fund management. P. Trescott, Financing American Enterprise 14 (1963). 
having a surplus of assets and channelling them to those economic units having a deficit of assets. ${ }^{18}$ The channelling process takes the form almost exclusively of credit extensions rather than direct investment because of the legislative restrictions imposed upon banks. National banks, for example, generally may not invest in the stock of other corporations, ${ }^{19}$ nor may their purchases of investment securities (defined as bonds, debentures, and other debt instruments) from any one obligor or maker exceed 10 per cent of their unimpaired capital and surplus. ${ }^{20}$ Furthermore, national banks and their subsidiaries ${ }^{21}$ must confine themselves to the "business of banking,"22 although the line separating banking from nonbanking activities is quite hazy. ${ }^{23}$ Banks which arguably cross the line may find themselves in the thicket of civil litigation brought by groups seeking to protect their competitive position from encroachment by the banks. ${ }^{24}$

Imposing such barriers to entry into nonbanking activities and forcing banks to employ credit extensions instead of direct investment may be economically inefficient for three reasons. First, the lending process may impose transaction costs upon the system of capital allocation that would not be incurred under a process of direct investment. For example, lending requires a complex collection system to insure the return of borrowed funds.

Secondly, existing restrictions frustrate efforts to achieve economies of scale which might be brought about if various services were provided by a central source. For example, a bank's data processing and credit information reporting facilities might serve a number of firms at lower cost than would result if each firm had to supply its own facilities. ${ }^{25}$ Thus, a one-bank holding company which owned both

18 Gurley \& Shaw, Financial Intermediaries and the Saving-Investment Process, $11 \mathrm{~J}$. Finance 257, 259 (1956).

1912 U.S.C. § 24, I Seventh (Supp. IV, 1969).

$20 I d$.

21 National banks are permitted to have subsidiaries provided that the subsidiaries engage only in those activities in which the banks themselves may engage. CoMPTROLIER's Manual for Natronal Banks of 7376 (1966, Supp. 1969).

2212 U.S.C. § 24, If Seventh (Supp. IV, 1969).

23 See Beatty, What are the Legal Limits to the Expansion of National Services?, 86 Banking L.J. 3 (1969). See also Harfield, Sermon on Genesis 17:20; Exodus 1:10, 85 BANkING L.J. 565 (1968).

24 See, e.g., Association of Data Processing Serv. Organizations v. Camp, 279 F. Supp. 675 (D. Minn. 1968), aff'd, 406 F.2d 837 (8th Cir. 1969), cert. granted, 395 U.S. 976 (1969) (data processing services); Arnold Tours v. Camp, 286 F. Supp. 770 (D. Mass. 1968), affd, 408 F.2d 1147 (lst Gir. 1969), petition for cert. filed, 37 U.S.L.W. 2589 (U.S. May 19, 1969) (No. 1407) (travel agency). See generally Note, Diversification by National Banks, 21 STAN. L. REv. 650 (1969).

25 Some evidence of an increase in efficiency may be inferred from the efforts of existing data processing concerns to keep banks from offering such services to their customers. 
insurance and automobile sales subsidiaries might be able to offer ${ }^{26}$ to a potential automobile purchaser a package consisting of the automobile, a loan to finance it, creditor life insurance, and liability-collision insurance. The cost for this package might be lower than the cost of the individual components because the holding company could avail itself of a single customer application processed centrally to ascertain whether the potential purchaser was a good credit risk and a good insurance risk. Furthermore, the transactions among the various holding company subsidiaries might operate more smoothly than would be the case if each subsidiary were an independent firm.

A third source of improved economic efficiency could come from the utilization of the managerial talents of bankers to replace less skilled managers in other firms who may be operating their businesses less efficiently than is possible. A bank may have developed a large and talented staff to service customers in a particular line of commerce, ${ }^{27}$ and this expertise might lead to improved efficiency if it were employed directly in the management of a particular firm.

A one-bank holding company can achieve these efficiencies because its investment policies are not governed by banking regulation. As indicated earlier, ${ }^{28}$ the one-bank holding company is free to invest its assets directly into almost any business it desires. Those holding companies organized by banks can be expected to obtain their operating revenue at least initially from their subsidiary bank. Although it is possible that such funds could flow from the bank to the holding company by way of extensions of credit, this is not very likely to occur to any significant extent for reasons discussed in the next section. ${ }^{29}$ More likely, the funds will come from the bank's earned surplus account and from its annual net earnings distributed to the holding company as the bank's sole shareholder.

Such efforts have met with mixed judicial results. In Association of Data Processing Serv. Organizations v. Camp, 406 F.2d 837 (8th Cir. 1969), supra note 24, the plaintiffs, a trade organization, were held to lack standing to litigate the legality of the Comptroller's ruling permitting national banks to provide data processing services upon request to their customers. But see Wingate Corp. v. Industrial Nat'l Bank, 288 F. Supp. 49 (D.R.I. 1968), vacated and remanded, 408 F.2d 1147 (1st Cir. 1969), in which the Court of Appeals for the First Circuit, relying upon the Bank Service Corporation Act, 12 U.S.C. $\$ \S 1861-5$ (1964), held that a competitor did have standing to litigate the issue. In neither case was a decision on the merits reached.

28 The holding company could not insist that the consumer accept the entire package, for such insistence would constitute an unlawful tie-in arrangement. See text at notes 88.92 infra.

27 Whitesell, Economics of the One-Bank Holding Company, 152 BANkERs MAGazine 28, 30 (Winter 1969).

28 See text at notes $9 \& 10$ supra.

29 See section II infra. 
If the bank is going to fund the holding company primarily through distribution of earnings (past and present), it is reasonable to ask why the holding company is necessary since the same earnings distribution could be made to the bank's existing shareholders without forming and operating a holding company. The shareholders in turn would then be free to invest in any area they desired since they are not restricted by banking regulations.

The above conclusion is susceptible to three objections. First, it is not likely that a bank would distribute a substantial part of its earnings to shareholders. If the bank retains its earnings, it may use them as reserves ${ }^{30}$ for expanding the bank's lending capacity and hence its profit-producing capacity. A distribution of earnings, on the other hand, has the effect of limiting the bank's lending capacity. ${ }^{\mathbf{3 1}}$

Secondly, it would seem that there is a loss of efficiency in distributing earnings to shareholders because of the higher transaction costs involved. With the holding company in existence the bank need only make a transfer of funds to a single entity as compared with a distribution to numerous shareholders. Furthermore, when the shareholders do receive their share of distributed earnings they face the problem of seeking out profitable investment opportunities, and they may be forced to pay broker's fees or to add additional sums of their own money to what would probably be a rather small amount received in the distribution of the bank's earnings before any investment would be reasonably practical.

The final reason why a distribution of bank earnings to its shareholders is not likely to produce the same economic results as a distribution to its parent holding company is that once the funds leave the bank's control, there is no assurance that any of the economies of scale or utilization of bank managerial talent discussed earlier ${ }^{32}$ would be achieved. In fact, it is virtually certain that such results could not be achieved without the holding company structure because the bank would continue to be prohibited from entering nonbanking areas.

The potential for increased economic efficiency in resource allocation serves to justify the creation of one-bank holding companies un-

30 Commercial banks operate on a fractional reserve system since they are required to maintain as reserves only a fraction of their deposit liabilities. Thus, if the reserve requirement was $20 \%$ for demand deposits, a single dollar of reserves would provide a basis for extending up to $\$ 5$ in loans by crediting the borrower's checking account.

31 A shareholder is likely to remain indifferent regardless of whether the bank distributes or retains its earnings as long as the increase in the bank's stock value caused by retaining the earnings is approximately equal to the rate of return which the shareholder could obtain by taking his part of the bank's earnings and investing it elsewhere.

32 See text at notes 25-27 supra. 
less, of course, there exist countervailing reasons for precluding the holding company's ability to invest directly in and thereby to enter nonbanking businesses. The next three sections consider the principal arguments which have been advanced in support of the proposition that one-bank holding companies should not be free to enter nonbanking businesses.

\section{Bank Holding Companies and Depositor Safety}

The funds which banks utilize for their lending operations come for the most part from time and demand deposits. ${ }^{33}$ Time deposits (e.g., savings accounts) are maintained in banks as opposed to competing financial institutions ${ }^{34}$ because of the bank's ability to offer a combination of safety, convenience, and liquidity in addition to the payment of interest. ${ }^{35}$ Demand deposits (checking accounts), on the other hand, provide a useful medium of exchange ${ }^{36}$ and are maintained in banks because no other institutions may lawfully provide checking account services. ${ }^{37}$

Persons placing funds in time and demand deposits do not believe that they are making an investment with risk of loss. ${ }^{38}$ If banks were to act imprudently with these funds, the resulting loss of depositor confidence might prompt a withdrawal of such funds from the banking system with a concomitant contraction of the money supply. ${ }^{39}$ Maximization of the safety of depositors' funds is thus a matter of public importance.

Opponents of one-bank holding companies have traditionally asserted that permitting the bank holding companies to enter nonbanking areas would endanger the safety of depositors' funds by tempting the banks which are affiliated with the holding companies to make improvident loans. According to this view, the temptation

33 As of June 30,1968 , demand and time deposits represented $86.5 \%$ of the combined capital-liabilities accounts of commercial banks. In dollar figures this represents approximately $\$ 400$ billion. P. Horvitz, Monetary Policy and the Financial System 46 (2d ed. 1969).

34 Commercial banks face competition for time deposits from a number of sources including mutual savings banks, savings and loan associations, and credit unions. Kreps, Characteristics of Local Banking Competition, in BANKING AND MONETARY STudies 319, 321 (D. Carson ed. 1963).

35 P. Trescott, Financing AMerican EnTERPrise 235 (1963).

36 Note, Bank Charter, Branching, Holding Company and Merger Laws: Competition Frustrated, 71 YALE L.J. 502, 505 (1962).

37 United States v. Philadelphia Nat'l Bank, 374 U.S. 321, 326 (1962).

38 Note, supra note 36 , at 506.

39 See generally M. FrifDman \& A. Schwartz, The Great Contraction: 1929-1933 (1965). 
would arise from two sources. First, banks might make loans to their nonbanking affiliates (including the parent holding company) even though such loans would not be justified under existing banking standards. ${ }^{40}$ Second, banks might extend credit to customers of their nonbanking affiliates even though the credit standards would indicate that such loans should not be made. ${ }^{41}$ In either case, it is alleged, the safety of depositors' funds would be seriously impaired.

Historical evidence fails to offer any support for such fears. During the spring of 1966, congressional hearings were held on various proposed amendments to the Bank Holding Company Act of 1956,42 including one that would have forced one-bank holding companies to divest themselves of their nonbanking affiliates. Approximately 550 one-bank holding companies were then in existence. ${ }^{43}$ One of the groups favoring the adoption of the amendment was the Board of Governors of the Federal Reserve System. ${ }^{44}$ The Board was forced to admit, however, that it did not "have evidence of abuses of relationship between one-bank holding companies and their affiliates." 45 In the end, the proposed amendment was rejected because "there was no substantial evidence of abuses occurring in one-bank holding companies."40

There are several reasons why one-bank holding companies are likely to continue to maintain an unblemished record. First, bankers work in glass offices; that is, the affairs of virtually all banks are open to continual investigation and examination by one or more of the federal bank regulatory agencies. ${ }^{47}$ These agencies have the power to supervise closely the day-to-day operations of banks. ${ }^{48}$ With respect to a national bank, investigation and examination extends to its affiliates" $^{49}$ to the extent "necessary to disclose fully the relations between

40 H.R. REP. No. 609, 84th Cong,, 1st Sess. 16 (1955).

41 Statement by William McChesney Martin, Jr., Chairman, Board of Governors of the Federal Reserve System, before the Committee on Banking and Currency, House of Representatives, April 18, 1969, reported in 55 FED. REs. BuLr. 331, 332 (1969).

4212 U.S.C. $\$ \S 1841-9$ (Supp. IV, 1969), amending 12 U.S.C. $\S \S 1841-8$ (1964).

43 STAFF REPORT, supra note 1 , at 5.

441966 Hearings, supra note 3, at 58-59.

45 Id. at 70.

46 S. REP. No. 1179, 89th Cong., 2d Sess. (1966).

47 See 12 U.S.C. $\$ 481$ (1964) (national banks subject to examination by Comptroller of Currency); 12 U.S.C. $\$ 483$ (1964) (Federal Reserve member banks subject to examination by Federal Reserve System); 12 U.S.C. $\$ 1820$ (b) (Supp. IV, 1969) (any bank insured by FDIC subject to examination by FDIC).

48 I K.C. Davis, Administrative Law Treatise \$ 4.04, at 247 (I958).

49 A one-bank holding company and its nonbank subsidiaries would be considered affiliates of a national bank. See 12 U.S.C. \$ 221 (Supp. IV, 1969), amending 12 U.S.C. $\S 221$ (1961), the relevant part of which is set out at notes 60 and 61 , infra. 
such banks and such affiliates and the effect of such relations upon the affairs of such bank." ${ }^{\circ}$ Furthermore, the Federal Deposit Insurance Corporation (FDIG) may inspect any insured bank at any time to determine whether it is engaged in "unsafe or unsound practices." such practices are detected, it may terminate the bank's insured status ${ }^{52}$ thereby throwing a national bank into receivership..$^{33}$

Extensions of bank credit are given special attention by the Federal Reserve System. Each reserve bank is required to "keep itself informed of the general character and amount of the loans and investments of its member banks with a view to ascertaining whether undue use is being made of bank credit for . . . [any] purpose inconsistent with the maintenance of sound credit conditions." 54 Improvident extensions of credit, if detected, can result in suspension of the offending bank from the Federal Reserve System. ${ }^{55}$

Banks are also limited in the nature and amount of credit which they can extend to their affiliates and investments which they can make therein. In general, no bank which is a member of the Federal Reserve System or which is insured by the FDIC may

(1) make any loan or an extension of credit to, or purchase securities under repurchase agreement from, any of its affiliates, or (2) invest any of its funds in the capital stock, bonds, debentures, or other such obligations of any such affiliate, or (3) accept any capital stock, bonds, debentures, or other such obligations of any such affiliate as collateral security for advances made to any person, partnership, association, or corporation, if, in the case of any such affiliate, the aggregate amount of such loans, extensions of credit, repurchase agreements, investments, and advances against such collateral security will exceed 10 per centum of the capital stock and surplus of such . . . bank, or if, in the case of all such affiliates, the aggregate amount of such loans, extensions of credit, repurchase agreements, investments, and advances against such collateral security will exceed 20 per centum of the capital stock and surplus of such . . . bank. ${ }^{56}$

The term "extension(s) of credit" includes "the discount of promissory notes, bills of exchange, conditional sales contracts, or similar paper." 57

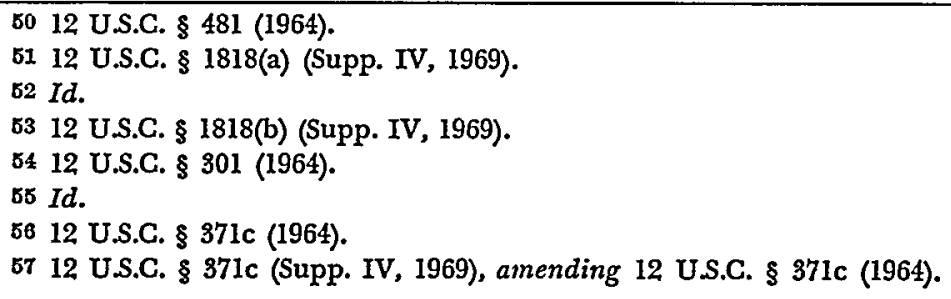


Within the above limitations, "each loan or extension of credit of any kind or character to an affiliate shall be secured by collateral in the form of stocks, bonds, debentures, or other such obligations,"58 and the value of such collateral must equal at least 120 per cent of the loan or other extension of credit unless the collateral consists of government obligations, in which case the collateral must have a value of 110 per cent of the loan or extension of credit. ${ }^{59}$

A one-bank holding company would be an "affiliate" of its own bank subsidiary ${ }^{60}$ as would each of the other subsidiaries of the holding company. ${ }^{61}$ To a great extent, then, cross-dealings between the bank and its holding company or other subsidiaries of the holding company are effectively restricted under existing law both quantitatively and in terms of collateral requirements.

The statutory provisions discussed above were not drafted as tightly as they might have been; consequently, a bank-holding company determined to circumvent their spirit while obeying their language can do so in three ways. First, the 120 per cent collateral provision can be effectively ignored if the collateral consists of the stocks, bonds, or debentures of the holding company itself. If the holding company or its subsidiaries are not able to repay their loan to the bank, then it is not very likely that their equity or debt instruments will be valuable to the bank for the purpose of securing the loan.

This loophole can be plugged by employing the rule of statutory construction that asserts that statutes will not be construed to make them absurd. In this case, it is absurd to permit the holding company's own stocks or bonds to serve as collateral for a loan since such collateral would surely be no more valuable than the holding company's promise to repay the loan.

The second technique which permits the holding company to circumvent the statute's salutary provisions involves a fairly simple scheme. The holding company first invests a large sum of money, say $\$ 10$ million, in the bank-subsidiary and receives in return a special class of stock, say class $\mathrm{S}$ (for sneaky). The bank has $\$ 10$ million extra

5812 U.S.C. § 371c (1964).

59 Id.

60 "[A]ny corporation ... (4) Which owns or controls, directly or indirectly, either a majority of the shares of capital stock of a ... bank or more than 50 per centum of the number of shares voted for the election of directors of a . . bank at the preceding election" is defined as an affiliate by 12 U.S.C. § 22la(4) (Supp. IV, 1969).

61 "[A]ny corporation ... (2) Of which control is held, directly or indirectly, through stock ownership or in any other manner, by the shareholders of a . . bank who own or control either a majority of the shares of such bank or more than 50 per centum of the number of shares voted for the election of directors of such bank at the preceding election" is defined as an affiliate by 12 U.S.C. $\$ 221 a(2)$ (1964). 
in its capital accounts and so may lend up to 20 per cent ( $\$ 2$ million) to the holding company and its subsidiaries without offending the statutory restrictions. After the loans have been made, the bank redeems the special class of stock, thereby returning the $\$ 10$ million to the holding company.

This loophole is only serious if the collateral for the bank's loan is not worth the amount loaned. Furthermore, it would not be stretching the language of the statute too much to prohibit the bank from engaging in any transaction with its holding company or other affiliates that would result in the 20 per cent loan limit being exceeded.

The third method of circumventing the statutory limits on extensions of credit to bank affiliates is brought about by the ability of national banks to engage in equipment leasing, ${ }^{62}$ whereby the bank purchases equipment on its own account and then leases it to some other firm, in this case to one of its affiliates. Such a lease is in substance nothing more than a security device with the equipment as the collateral. The lease form is used to take advantage of tax savings that may be possible. ${ }^{63}$

Support for the proposition that this type of equipment leasing is merely a disguised security transaction is derived from section 1-201(37) of article 1 of the Uniform Commercial Code. ${ }^{64}$ There are a few reported cases in which leases were held to be security devices. ${ }^{65}$ If such a leasing arrangement by a bank is construed as a security device for an extension of credit, then the transaction fairly easily fits into the scheme of restrictions imposed upon bank-affiliate transactions.

Apart from the statutory restrictions, there are other reasons why banks are not likely to engage in conduct which would endanger their depositors' funds. Bank directors are personally liable for any loss resulting from their participation or acquiescence in any violation of

62 The Comptroller's Manual for National Banks provides that "a national bank may become the owner or lessor of personal property acquired upon the specific request and for the use of a customer and may incur such additional obligations as may be incident to becoming an owner and lessor of such property." COMPTroller's MANUAL FOR NATIONAL BANks ๆ 3400 (1966).

63 See Riordan \& Duffy, Lease Financing, 24 Bus. LAw. 763 (1969).

64 "Unless a lease ... is intended as security, reservation of title thereunder is not a 'security interest' .... Whether a lease is intended as security is to be determined by the facts of each case; however, (a) the inclusion of an option to purchase does not of itself make the lease one intended for security, and (b) an agreement that upon compliance with the terms of the lease the lessee shall become or has the option to become the owner of the property for no additional consideration or for a nominal consideration does make the lease one intended for security." UNIFORM COMMERcIaL CODE \$ 1-201(37) (1962 version).

65 See, e.g., In re Pomona Valley Inn, 4 UCC REP. SERv. 893 (D.C.C.D. Cal. 1967); In re Transcontinental Industries, Inc., 3 UCC REP. SERv. 235 (N.D. Ga. 1965). 
the above limitations on dealings among bank affiliates. ${ }^{66}$ Furthermore, directors are personally liable at common law for failure to use ordinary care in the supervision of a bank's affairs, ${ }^{67}$ and such liability cannot be avoided by delegating responsibility to the bank's officers. ${ }^{68}$

Another reason why banks are not likely to make improvident loans is that if a loan is not repaid because of the insolvency of the borrower, the lending institution's profits are reduced. Since banks are profitoriented like any other firm, it would be irrational for them to extend credit to anyone who is not likely to repay the loan. ${ }^{69}$ This principle applies regardless of whether the borrower is one of the bank's affiliates or a customer of one of the affiliates.

Another factor that should not be ignored in assessing the probability that one-bank holding companies will foster abusive banking practices is that of public confidence in a particular bank as opposed to banks in general. To survive, a bank must be able to attract and maintain deposits, thereby permitting it to engage in profitable credit transactions. Because of the competitive environment in which banks exist, ${ }^{70}$ any given bank which deviates too far from what the public considers to be acceptable banking standards is likely to find itself without depositors or with a very substantial decline in the level of its deposits. Thus, the same profit motive which might tempt a bank to engage in questionable conduct also serves to countervail this temptation. This countervailing force should exist regardless of whether the bank holding company is dominated by bankers or by the managers of a nonbank conglomerate.

Should a bank act unwisely, the existence of federal deposit insurance shifts most of the risk of loss away from depositors who are subject to only a temporary inconvenience. ${ }^{71}$ If the existence of nonbanking affiliates is thought to pose greater dangers to depositor safety, perhaps the best solution would be to grant to the FDIC the power to assess insurance contributions on the basis of a bank's involvement in such nonbanking activities. ${ }^{72}$

As indicated earlier, ${ }^{73}$ it is most unlikely that the bank will fund

66 See 12 U.S.C. § 501a (1964).

67 Atherton v. Anderson, 99 F.2d 883 (6th Cir. 1938) (directors liable for negligently permitting loans to exceed statutory limitation for single borrower).

68 Bowerman v. Hammer, 350 U.S. 504 (1919).

69 Cf. Note, Bank Charter, Branching, Holding Company and Merger Laws: Competition Frustrated, 71 YALE L.J. 502, 508 (1962).

70 See note 34 supra.

71 Turner, The Scope of Antitrust and Other Economic Regulatory Policies, 82 HARv.

L. REv. 1207, 1234 (1969).

72 The assessment rate for FDIC insurance is currently uniform. 12 U.S.C. $\$ 1817$ (b) (1964).

73 See text at notes 25-27 supra. 
its holding company by lending its depositors' funds for the reasons which have been considered in this section. The most likely source of funds is the bank's earned surplus account. Will the use of earnings and earned surplus have an adverse effect on depositor safety? Not significantly. Existing law requires that a national bank maintain a certain minimum capitalization ${ }^{74}$ in order to provide a cushion for depositors, should a portion of a bank's loans become uncollectable or its securities decline in value. ${ }^{75}$ However, for more than 50 years, capital as a percentage of bank assets has steadily declined;76 and no objections appear to have been raised, probably because the existence of federal deposit insurance fills the void left by the declining capital accounts. As long as banks maintain the minimum capitalization required by law, depositors are subjected to no greater risk than that prescribed by Congress.

\section{Can Bank Holding Companies Be Trusted Not to Violate the ANTitrust Laws?}

Apart from the issue of depositor safety, opponents of one-bank holding companies allege that two forms of anticompetitive behavior are likely to arise if banks are permitted to enter nonbanking businesses. First, a bank might refuse to extend credit to a firm which competes with or is about to compete with one of the bank's own affiliates. ${ }^{77}$ Secondly, a bank might refuse to extend credit to a firm unless the firm agreed to purchase goods or services from the bank's affiliates. ${ }^{78}$ In both cases, the restrictions on competition would occur in the product markets served by the affiliates of the bank, although the precise effects upon competition would be dependent to some extent on the number of firms present in the relevant market.

Both of these patterns of behavior may exist in analogous situations even without the presence of a one-bank holding company. For example, a bank which has extended credit to one business establishment may refuse to extend credit to a competing business for fear that the competition might endanger the ability of one or both of the firms to

74 National banks must maintain a minimum of from $\$ 50,000$ to $\$ 200,000$ in capital depending upon the population of the community in which they are located. 12 U.S.C. \$ 51 (1964). In addition, a national bank must build up a surplus at least equal to its required minimum capitalization before it may distribute earnings to its shareholders. 12 U.S.C. \$ 60(a) (1964).

75 P. Horvitz, Monetary Policy and the Financial System 48 (2d ed. 1969).

$76 \mathrm{Id}$.

77 See 1966 Hearings, supra note 3, at 71.

78 See Hearings on S. 76 and S. 1118 Before the Senate Comm. on Banking and Currency, 83rd Cong., 1st Sess., pt. 1, 24 (1958). 
repay their loans. ${ }^{79}$ Similarly, a bank may refuse to extend credit to a firm unless the firm agxees to use some other bank product such as a lock-box service. There is thus nothing peculiar in the holding company structure as far as the creation of the possibility for such behavior is concerned.

It does not, however, appear very likely that a bank would possess the economic power necessary to engage in such anticompetitive conduct. If such conduct is to be at all effective, it must be assumed that the firms seeking bank credit have no alternative sources for obtaining funds. At the very least this means that no other bank in the area would be willing to extend credit to such firms and that the firms themselves would be unable to raise funds by selling securities to the investing public. The recent upsurge in the formation of one-bank holding companies is taking place in the major metropolitan areas ${ }^{80}$ where alternative sources of financing are likely to be available. Considerable doubt is thus cast upon the premise which underlies this proposition.

Even greater doubt is cast upon the validity of the proposition by the fact that those who advocate it take an inconsistent approach to the problems ostensibly generated by one-bank holding companies. This inconsistency is well illustrated by one of the current legislative proposals ${ }^{81}$ designed to restrict the activities of one-bank holding companies. This bill would permit a bank holding company to acquire only those subsidiaries which are "financial or related to finance in nature or of a fiduciary or insurance nature." 82 Such a provision would make little sense if the anticompetitive behavior argument were meant to be taken seriously, for such behavior is just as likely to be present with respect to "financial" subsidiaries as it is with respect to nonfinancial ones. The other legislative proposals for restricting one-bank holding company activity also contain similar provisions. ${ }^{83}$

If the banks and their holding companies were to engage in these forms of anticompetitive behavior, they would be inviting antitrust litigation. A refusal to extend credit to a competitor of a bank's affiliate in order to eliminate that competitor from the market is arguably

\footnotetext{
79 Cf. Note, Bank Charter, Branching, Holding Company and Merger Laws: Competition Frustrated, 71 YALE L.J. 502, 504 (1962).

80 See STAFF RePORT, supra note 1 , at 6.

81 H.R. 9385, 91st Cong., lst Sess. (1969).

82 Id. \& 2(4)(b).

83 Both H.R. 946, 91st Cong., 1st Sess. (1969), and H.R. 6778, 91st Cong., Ist Sess. (1969), retain the language of the Bank Holding Company Act of 1956, 12 U.S.C. $\$ \$ 1841-9$ (Supp. IV, 1969), amending 12 U.S.C. $\$ \$ 1841-8$ (1964), which permits investment in corporations of a "financial, fiduciary, or insurance nature." 12 U.S.C. $\S 1843$ (c)(8) (Supp. IV, 1969).
} 
a violation of both section $1^{84}$ and section $2^{85}$ of the Sherman Act. The fact that the combination or conspiracy is between commonly owned corporations would not prevent the application of the antitrust laws. ${ }^{86}$

With respect to the possibility of tying agreements, if there could ever have been any doubt that such arrangements were unlawful, ${ }^{87}$ the doubts have been laid to rest by the recently decided case of Fortner Enterprises, Inc. v. United States Steel Corp. ${ }^{88}$ a private treble damage action brought under the Sherman Act. The gravamen of plaintiff's complaint was that in order for it to obtain loans totaling more than $\$ 2$ million from a wholly owned subsidiary of United States Steel, the proceeds of which were to be used for the purchase and development of real estate, it had to agree to erect on each of the lots so purchased a prefabricated house manufactured by United States Steel. Plaintiff intended to erect prefabricated houses on these lots but was not especially pleased with being forced to use United States Steel's products since they cost more than $\$ 400$ over the price of competing manufacturers' prefabricated houses.

The Court found no difficulty in recognizing that the challenged conduct involved a traditional tying arrangement in which the plaintiff was required to accept a tied product (prefabricated houses) as a condition of being allowed to purchase the tying product (credit). The Court vigorously dismissed the defendant's argument that credit was not a product which could be utilized for tying:

$[\mathrm{W}] \mathrm{e}$ can find no basis for treating credit differently in principle from other goods and services. ... [T] [Te-ins involving credit can cause all of the evils that the antitrust laws have always been intended to prevent, crippling other companies that are equally if not more efficient in producing their own products. Therefore, the same inquiries must be made as to economic power over the tying product and substantial ef-

84 "Every contract, combination in the form of trust or otherwise, or conspiracy, in restraint of trade or commerce among the several States, or with foreign nations, is hereby declared to be illegal ...." 15 U.S.C. $\$ 1$ (1964).

85 "Every person who shall monopolize, or attempt to monopolize, or combine or conspire with any other person or persons, to monopolize any part of the trade or commerce among the several States, or with foreign nations, shall be deemed guilty of a misdemeanor . ..." 15 U.S.C. \& 2 (1964).

86 See Timken Roller Bearing Co. v. United States, 341 U.S. 593 (1951).

87 Cf. United States v. General Motors Corp., I21 F.2d 376 (7th Cir. 1941), cert. denied, 314 U.S. 618 (1941). General Motors' subsidiary, General Motors Acceptance Corporation, was engaged in the financing of automobiles at both the wholesale and retail level. General Motors was found guilty of conspiring to restrain the financing of its automobiles by using its monopoly power as a manufacturer to force its dealers to use the services of General Motors Acceptance Corporation.

88394 U.S. 495 (1969). 
tect in the tied product market, but where these factors are present no special treatment can be justified solely because credit, rather than some other product, is the source of the tying leverage used to restrain competition. ${ }^{89}$

In view of the existing laws and the climate of their strict enforcement, ${ }^{90}$ it seems almost impossible to justify restricting the activities in which one-bank holding companies may engage on the basis of a fear that unrestricted activity will lead to anticompetitive behavior.

\section{Big Bank, Bad Bank}

The final argument advanced in opposition to one-bank holding companies is that they would permit an undesirable concentration of economic power. Thus, Representative Widnal, who introduced H.R. 9385, predicted that the trend toward one-bank holding companies would result in "a fundamental restructuring of our economy, from one in which economic and financial power is widely dispersed, into a structure dominated by some 50 or 75 huge centers of economic power."91

The specter of the giant corporation appears to throw as much fear into the hearts of 20th-century man as the Four Horsemen of the Apocalypse did to the medieval Europeans, ${ }^{92}$ and perhaps with equal justification. Court cases are replete with warnings of the evils of bigness and the desirability of preserving the small firm. Thus, in United States $v$. Swift \& Co., ${ }^{93} \mathrm{Mr}$. Justice Cardozo warned that "size carries with it an opportunity for abuse that is not to be ignored."94 In United States v. Aluminum Co. of America, ${ }^{95}$ Judge Learned Hand noted

89 Id. at 509.

90 Current periodicals have noted that the Department of Justice's Antitrust Division appears to be engaged in a crackdown on conglomerates. See, e.g., BusINEsS WEEk, June 21,1969 , at 120 .

91115 Cong. REc. H2012 (daily ed. March 24, 1969).

92 United States Attorney General John Mitchell has pledged a vigorous offensive against what he refers to as "super-concentration"-the increasingly larger share of United States business that is being done by a relatively small number of firms. He has warned that this super-concentration poses dangers "to our economic, political and social structure [which] cannot be overestimated." Address before the Georgia Bar Ass'n, June 6, 1969, in Wall Street Journal, June 9, 1969, at 5, col. 1. Congressman Emanuel Celler (D.-N.Y.), Chairman of the House Judiciary Committee and the Committee's antitrust subcommittee, has suggested the need for a new law limiting the asset size of corporations to some designated amount regardless of anticompetitive effects. Address before the American Management Ass'n, June 12, -1969, in Wall Street Journal, June 13, 1969, at 2, col. 3 .

93286 U.S. 106 (1932).

$84 I d$, at 116.

95148 F.2d 416 (2d Cir. 1945). 
that throughout the history of the antitrust laws "it has been constantIy assumed that one of their purposes was to perpetuate and preserve, for its own sake and in spite of possible cost, an organization of industry in small units." Finally, there is Mr. Justice Douglas' impassioned dissent in United States v. Columbia Steel Co.:97

[A]ll power tends to develop into a government in itself. Power that controls the economy should be in the hands of elected representatives of the people, not in the hands of an industrial oligarchy. Industrial power should be decentralized. It should be scattered into many hands so that the fortunes of the people will not be dependent on the whim or caprice, the political prejudices, the emotional stability of a few self-appointed men. The fact that they are not vicious men but respectable and social-minded is irrelevant. That is the philosophy and command of the Sherman Act. It is founded on the theory of hostility to the concentration in private hands of power so great that only a government of the people should have it. ${ }^{98}$

The fear of bigness is not limited to the field of banking; all conglomerate mergers are suspect. To some extent, the desire to avoid economic concentration has judicially manifested itself in more ways than mere warnings. ${ }^{99}$ In fact, some commentators see a clear trend toward the judicial condemnation of any conglomerate merger principally on the basis of the merging firm's size. ${ }^{100}$

There is, of course, an opposing point of view. During the recent congressional hearing on economic concentration, ${ }^{101}$ for example, one economist testified that "absolute size is absolutely irrelevant."102 Professor Galbraith believes that a great deal of this country's growth and progress is due to the efforts and capabilities of the giant corporations. ${ }^{103}$

$90 \mathrm{Id}$. at 429.

97334 U.S. 495 (1948).

$98 \mathrm{Id}$. at 536.

99 See, e.g., FTG v. Proctor \& Gamble Co., 386 U.S. 568 (1967). Defendant was a large diversified manufacturer of household products with annual sales in excess of $\$ 1$ billion. Defendant's acquisition of the leading manufacturer of liquid bleach (Clorox) was held to violate $\S 7$ of the Clayton Act, I5 U.S.C. $\S 18$ (1964), primarily because of the increased concentration in the bleach industry which would result if the acquisition were permitted.

100 See, e.g., Rill, Conglomerate Mergers: The Problem of "Superconcentration," 14 U.C.L.A.L. REv. 1028, 1036 (1967).

101 Hearings on Economic Concentration Before Subcomm. on Antitrust and Monopoly of the Senate Comm. on the Judiciary, 88th \& 89th Cong., 1st \& $2 d$ Sess., pts. 1-5 (1964-66). 102 Id. at 228.

103 J.K. Galbrami, ThE New Industrial State (1967). 
Even if one accepts the position that economic concentration is undesirable per $s e$, it does not follow that permitting one-bank holding companies to enter nonbanking areas will lead to such concentration. It is beyond doubt that a one-bank holding company is subject to the antitrust laws. ${ }^{104}$ Expansion through the holding company structure is thus subject to the same scrutiny as would be the case in any other type of corporate acquisition. Furthermore, even supporters of restrictive legislation would permit the bank holding company to enter areas closely related to banking or finance. ${ }^{105}$ Entry into such areas could produce the same type of concentration as entry into other areas; thus, in the final analysis, reliance is still placed upon the antitrust laws.

\section{Some Problems in Need of Solution}

There appears to be no significant objection to the formation of one-bank holding companies as such; the major controversy concerns the type of activities in which the holding companies will be permitted to engage. ${ }^{106}$ This seems quite peculiar since it would appear that the major source of difficulty lies with the holding company structure and not with the particular areas of business in which the holding company might seek entry.

The factor which is most responsible for the existence of such difficulty is the presence of an enormous amount of assets which banks hold in their fiduciary capacity as corporate trustees for personal trusts and employee pension funds. Commercial banks hold more than $\$ 250$ billion of assets in their trust departments, more than insurance companies and mutual funds combined. ${ }^{107}$ To a large extent, the instruments which create these fiduciary accounts give the banks virtually unlimited discretion to invest the assets. ${ }^{108}$

Although some commentators have suggested that banks, like other corporate trustees, have established reputations for honesty and reli-

104 On June 12, 1969, the Justice Department threatened to file suit to prevent the acquisition of $\mathrm{Chubb}$ Corporation (an insurance concern with several subsidiary insurance corporations) by First National City Corporation, a one-bank holding company formed by First National City Bank of New York. While Chubb wanted to fight, First National City surrendered. Wall Street Journal, June 16, 1969, at 2, col. 3.

105 See notes 82-84 and accompanying text supra.

106 See, e.g., statement of Charles Walker, Undersecretary of the Treasury, before the House Committee on Banking and Currency, reported in BNA ANTrrRust \& Trabe Reg. ReP., No. 406, April 22, 1969, at AA-1.

107 See Staff of Subcomm. on Domestic Finance of the House Comm. on Banking and Currency, 90th Cong., 2d Sess., Commercial Banks and Their Trust Activities: EMerging Influence on the AMerican Economy vol. 2, at 19 (Subcomm. Print 1968).

108 Compare D. Baum \& N. Stiles, The Silent Partners 50 (1965) with Presment's Committee on Corporate Pension funds and Other Private Retirement and Welfare Programs, Public Policy and Private Pension Programs 75 (1965). 
ability and will therefore exercise self-discipline in order to maintain their reputation, ${ }^{109}$ the fear of possible abuses is aroused by the many reported decisions in which banks have demonstrated their willingness to engage in self-dealing at the expense of those to whom they owe fiduciary obligations. ${ }^{110}$

\section{A. Management Self-Perpetuation}

Before the popularity of the one-bank holding company structure was evident, it became clear that the trust departments of many state banks were undertaking a policy of purchasing their own bank stock on behalf of their fiduciary accounts. ${ }^{111}$ If a bank's stock were widely held, a controlling interest in a bank could be achieved in this way by purchasing considerably less than 51 per cent of the outstanding shares. ${ }^{112}$ Having gained control of a bank, the bank's directors would be in a position to perpetuate themselves in office by causing the stock held in the fiduciary accounts to be voted for their reelection at each annual meeting.

Management self-perpetuation through this technique is clearly undesirable for a number of reasons. First, the managers are using other persons' funds for their own self-interest, thereby violating one of the cardinal tenets of fiduciary fidelity. ${ }^{113}$ Second, unlike proxy solicitations under section 14 of the Securities Exchange Act of 1934,,14 no disclosure to anyone need be made about anything. Thirdly, attempts to oust the incumbent management slate are likely to prove futile regardless of whether the technique employed is a proxy solici-

\footnotetext{
109 See, e.g., Comment, Cleveland Trust Co. v. Eaton: Can a Corporate Trustee Vote Its Own Shares Held in Trust?, 54 VA. L. REv. 327, 337 (1968).

110 See, e.g., Rippey v. Denver United States Nat'l Bank, 260 F. Supp. 704 (D. Colo. 1966); Pennsylvania Co. v. Wilmington Trust Co., 40 Del. Ch. 567, 186 A.2d 751 (Ct. Chanc. 1962); In re Ferris, 19 Ohio Op. 2d 428, 182 N.E.2d 78 (C.P. 1962).

111 "Over $93 \%$ of the banks surveyed hold some shares in their own bank. Over $56 \%$ hold $5 \%$ or more of their own shares. Just under $30 \%$ hold more than $10 \%$ of their own shares. Seven banks, all major commercial banks in their communities, hold more than one-third of their own shares." STAFF OF SUBCOMrm. ON DOMESTIC FinancE OF THE House Comm. on Banking and Currency, 89th Cong., 2d Sess., Report on Bank Stock OwnerSHIP AND CONTROL I (Subcomm. Print 1966).

112 Cf. Denver \& R.G.W.R.R. v. United States, 387 U.S. 485 (1967).

113 Courts have generally prohibited any self-dealing by a trustee that could harm the beneficiaries, even where no actual harm is shown. See Scott, The Trustee's Duty of Loyalty, 49 HARv. L. REv. 521, 564-5 (1936). A state bank's purchase of its own stock on behalf of its trust accounts was held to be a breach of fiduciary duty in Cleveland Trust Co. v. Eaton, 40 Ohio Op. 2d 460, 229 N.E.2d 850 (C.P. 1967) (alternate holding), but an opposite result was reached in Graves v. Security Trust Co., 369 S.W.2d 114 (Ky. 1963). State law is generally silent on the question of whether banks may vote their own shares held in trust. Note, The Corporate Fiduciary's Power to Vote Its Own Stock, 68 Colum. L. Rev. 116 (1968); Comment, supra note 109.

11415 U.S.C. § 78n (Supp. IV, 1969).
} 
tation or tender offer, since management can be expected vigorously and consistently to resist such efforts by refusing to vote any of the stock held in fiduciary accounts in favor of the ouster.

The undesirability of management self-perpetuation in this fashion accounts for the fact that national banks are generally prohibited from engaging in this tactic:

$[I] n$ the election of directors, shares of its own stock held by a national bank as sole trustee, whether registered in its own name as such trustee or in the name of its nominee, shall not be voted by the registered owner unless under the terms of trust the manner in which such shares shall be voted may be determined by a donor or beneficiary of the trust and unless such donor or beneficiary actually directs how such shares shall be voted. ... ${ }^{115}$

It is self-evident that nothing in the above statute would prohibit a national bank from purchasing for its trust accounts the shares of its parent corporation (i.e., the holding company). That being the case, management self-perpetuation can be accomplished as readily as the state banks were (are?) managing to do it. In other words, the very existence of a one-bank holding company permits this salutary statute to be circumvented, even if the holding company makes no acquisitions at all.

Fortunately, the Comptroller of the Currency ${ }^{116}$ is not entirely helpless, for he has prescribed that

... funds held by a national bank as fiduciary shall not be invested by the purchase of stock or obligations of the bank or its affiliates unless authorized by the instrument creating the relationship or by court order or by local law. ${ }^{117}$

Unfortunately, the Comptroller has managed to say both too little and too much in his regulation. He has said too little because he has failed to define the term "affiliates." Is a one-bank holding company an affiliate of its subsidiary bank? An affirmative answer is required, and such an answer can be based upon any of three sources. First, the Comptroller can issue an ex cathedra pronouncement that the term "affiliates" will be interpreted to include the one-bank holding company parent of a bank subsidiary (after all, it is his regulation,

11512 U.S.C. § 61 (Supp. IV, 1969).

116 The Comptroller of the Currency is the chief officer of the administrative agency having general regulatory and supervisory power over national banks. 12 U.S.C. § 1 (Supp. IV, 1969).

11712 G.F.R. \& 9.12(c) (1969) (self-dealing). 
isn't it?). Secondly, the Comptroller may rely by analogy upon the language of his regulation section 9.12(a) which prohibits investments by banks in an "organization in which there exists such an interest as might affect the exercise of the best judgment of the bank. . .."118 Thirdly, the Comptroller may rely upon the definition of affiliates used in the Federal Reserve Act which includes any corporation that "owns or controls, directly or indirectly, either a majority of the shares of capital stock of a ... bank or more than 50 per centum of the number of shares voted for the election of directors ...."119

The Comptroller's regulation says too much for two reasons. First, the regulation permits investment of trust funds in affiliates if the trust instrument so provides. This creates the risk that every national bank in the country which has a trust department will adopt a standard trust form giving the banks this investment power. Persons establishing fiduciary accounts may not realize the significance of granting such power, or they may not care if the bank is granted such a power. To the extent that management self-perpetuation is detrimental to the shareholders of one-bank holding companies, persons establishing fiduciary accounts should not be given the opportunity to grant such investment powers.

The second way in which the regulation says too much is by permitting investments in bank affiliates if local law so provides. This part of the regulation was probably designed to insure the competitive equality of national banks vis-à-vis state banks. ${ }^{120}$ Considering the almost unlimited range of investment opportunities open to national banks it would not appear very likely that a national bank would lose trust accounts to state banks if this "local law" provision were eliminated.

Apart from the Comptroller's regulation discussed above, investment of trust funds in a bank's parent holding company can probably be eliminated by judicious utilization of the Federal Deposit Insurance Corporation's supervisory powers. The FDIC insures a bank's trust accounts in much the same way it insures the accounts of other bank depositors. ${ }^{121}$ Using its powers to terminate the insured status of a bank engaged in "unsafe or unsound" practices, ${ }^{122}$ the FDIC can regulate this aspect of one-bank holding companies.

11812 C.F.R. § 9.12(a) (1969) (self-dealing).

11912 U.S.C. \$ 221a(4) (Supp. IV, 1969).

120 Compare First Nat'l Bank of Logan v. Walker Bank \& Trust Co., 385 U.S. 252 (1966) with Dickinson v. First Nat'l Bank in Plant City, 400 F.2d 548 (5th Cir. 1968), cert. granted, 394 U.S. 996 (1969).

12112 U.S.C. \& 1817 (i) (Supp. IV, 1969).

12212 U.S.C. § 1818(a) (Supp. IV, 1969). 


\section{B. The Securities Exchange Act of 1934}

If a firm expands internally, it is quite difficult to argue that a reduction in competition has occurred, for obviously a new firm has entered the market. On the other hand, if a corporation enters the market by acquiring a firm already there, there is at least a basis for asserting that the acquisition could have anticompetitive consequences. For example, it may be alleged that the acquiring firm would have entered the market by internal expansion if it had not acquired the existing firm. ${ }^{123}$ Or it may be alleged that the acquiring and acquired firms will engage in reciprocal buying arrangements to the detriment of other competitors of the acquired firm.124

To the extent that such arguments are sound, ${ }^{125}$ a policy which enhances the ability of one firm to acquire another is less desirable than one which does not. The one-bank holding company structure combined with a bank's fiduciary accounts falls into the less desirable category because of a rather serious shortcoming in the Securities Exchange Act of $1934 . .^{126}$

Most corporations desiring to acquire another firm by first obtaining a large segment of the stock of the desired firm must face section 16(a) of the Securities Exchange Act, ${ }^{127}$ which in general provides for the

123 See, e.g., United States v. EI Paso Natural Gas Co., 376 U.S. 651 (1964). See also Davidow, Conglomerate Concentration and Section Seven: The Limitations of the AntiMerger Act, 68 Colum. L. REv. 1231, $1241-9$ (1968).

124 See, e.g., United States v. International Tel. and Tel. Corp., Civil No. 69 C 924 (N.D. Ill., filed April 28, 1969), where the gravamen of the Justice Department's complaint which seeks to enjoin the acquisition of Canteen Corporation by ITT is that "The power of ITT and Canteen to employ reciprocity or benefit from reciprocity in the furnishing of vending and in-plant feeding services will be substantially increased."

125 Both propositions are open to very serious doubt as to their economic validity. If a firm decides to expand into a new market (either product or geographic), the decision must be based upon the firm's prediction that such an expansion will yield a rate of return on invested capital sufficiently great to warrant the expenditure of funds for that purpose as opposed to investing the funds elsewhere. There is no reason to assume that the costs of expansion through acquisition will approximately equal the cost of expansion through internal growth. It may be that the only satisfactory rate of return is achieved by expansion through acquisition. Consequently, the fact that a firm seeks to expand through acquisition does not necessarily mean that it would be willing to expand through internal growth if it were precluded from employing the first alternative. With respect to reciprocity, unless the firm's managers act irrationally-a position which economic analysis assumes is never the case-a firm will buy products from its affiliates only as long as such products cost no more than competing products produced elsewhere. Other firms selling in the affiliates' market are still able to compete for the business of the acquiring firm.

12615 U.S.C. \$ 78n (Supp. IV, 1969).

12715 U.S.C. $\$ 78 \mathrm{p}(\mathrm{a})$ (1964) provides:

Every person who is directly or indirectly the beneficial owner of more than 10 per centum of any class of any equity security (other than an exempted security) which is registered pursuant to section $78 l$ of this title, or who is a director 
giving of public notice by any person beneficially owning more than 10 per cent of a corporation's stock. Such public notice will alert the target corporation which may then begin employment of various devices to avoid a takeover. ${ }^{128}$ The bank holding company, on the other hand, may acquire through the trust department of its bank subsidiary as much stock of the target corporation as it deems necessary without complying with the section 16 (a) disclosure requirements, as long as no single trust account owns more than 10 per cent of the stock of the target corporation. This occurs because the statute speaks in terms of beneficial ownership rather than legal ownership.

The holding company may also ignore with impunity the "short swing" profits provisions of section 16(b), ${ }^{129}$ again because of the use of the concept of beneficial ownership. Even without a holding company, a bank is free to obtain "short swing" profits in flagrant violation of the spirit but not the letter of the Securities Exchange Act.

Why does the Securities Exchange Act employ the beneficial ownership concept? The answer is that without it a large stockholder could transfer his stock to a trust and thereby escape the requirements of the Act. On the other hand, the rise of large corporate trustees now warrants a change in the wording of the Act so that section 16 would

or an officer of the issuer of such security, shall file, at the time of the registration of such security on a national securities exchange or by the effective date of a registration statement filed pursuant to section $78 l(\mathrm{~g})$ of this title, or within ten days after he becomes such beneficial owner, director, or officer, a statement with the Commission (and if such security is registered on a national securities exchange, also with the exchange) of the amount of all equity securities of such issuer of which he is the beneficial owner, and within ten days after the close of each calendar month thereafter, if there has been a change in such ownership during such month, shall file with the Commission (and if such security is registered on a national securities exchange, shall also file with the exchange), a statement indicating his ownership at the close of the calendar month and such changes in his ownership as have occurred during such calendar month.

128 "Tender offers are frequently arranged in secret in hopes of catching the target management unprepared to respond effectively." Note, Defensive Tactics Employed by Incumbent Managements in Contesting Tender Offers, 21 SrAN. L. REv. 1104, 1106 (1969). This note provides a useful collection and analysis of the various methods which may be employed by corporate managers to thwart potential takeover efforts.

129 I5 U.S.C. $\$ 78 \mathrm{p}(\mathrm{b})(1964)$ provides:

For the purpose of preventing the unfair use of information which may have been obtained by such beneficial owner, director, or officer by reason of his relationship to the issuer, any profit realized by him from any purchase and sale, or any sale and purchase, of any equity security of such issuer (other than an exempted security) within any period of less than six months, unless such security was acquired in good faith in connection with a debt previously contracted, shall inure to and be recoverable by the issuer, irrespective of any intention on the part of such beneficial owner, director, or officer in entering into such transaction of holding the security purchased or of not repurchasing the security sold for a period exceeding six months. . . This subsection shall not be construed to cover any transaction where such beneficial owner was not such both at the time of the purchase and sale, or the sale and purchase, of the security involved, or any transaction or transactions which the Commission by rules and regulations may exempt as not comprehended within the purpose of this subsection. 
include any corporate trustee controlling 10 per cent or more of any non-exempt security required by the Act to be registered.

It seems fairly clear that there is one tactic which not even banks could get away with. To make a desired acquisition, a one-bank holding company might be tempted to order its bank subsidiary to sell the target corporation's stock (assuming, of course, that the bank's trust department owns a substantial quantity of such stock), in an effort to drive down the market price, causing other stockholders to panic and either sell their shares or to look with favor upon a takeover bid put forth by the holding company.

Such a tactic would be a violation of section 9(a)(2) of the Securities Exchange Act which makes it illegal for any person:

To effect, alone or with one or more other persons, a series of transactions in any security registered on a national securities exchange creating actual or apparent active trading in such security or raising or depressing the price of such security, for the purpose of inducing the purchase or sale of such security by others. ${ }^{130}$

Considering the recent revelation that bank trust departments do in fact own large percentages of the stock of major corporations, ${ }^{131}$ the existence of this provision should provide considerable protection against any possible abusive practices that could be engendered by an acquisition-oriented one-bank holding company.

\section{The Clayton Act}

The acquisition of control by one corporation engaged in commerce of another corporation also engaged in commerce is often challenged under section 7 of the Clayton Act. ${ }^{132}$ There has never been a reported case in which a bank's acquisition, on behalf of its trust accounts, of the stock of two or more firms arguably competing with one another in some line of commerce has ever been challenged under this law. The lack of litigation is perhaps due to the secrecy which shrouds trust department activities, making it difficult or impossible for an

130 I5 U.S.C. § 78i(a)(2) (1964) (emphasis supplied).

131 See Staff Report of Subcomm. on Domestic Finance of the House Comm. on Banking and Currency, 90th Cong., 2d Sess., Commercial Banks and Their Trust Activities: EMerging Influence on the American Economy, vol. 2, at 19 (Subcomm. Print 1968).

13215 U.S.C. \& 18 (1964) provides:

No corporation engaged in commerce shall acquire, directly or indirectly, the whole or any part of the stock or other share capital and no corporation subject to the jurisdiction of the Federal Trade Commission shall acquire the whole or any part of the assets of another corporation engaged also in commerce, where in any line of commerce in any section of the country, the effect of such acquisition may be substantially to lessen competition or to tend to create a monopoly. 
enforcement agency to learn of possible violations. Or perhaps the banks were able to satisfy the "solely for investment" exemption"133 and thereby avoid the prohibitions of the Clayton Act altogether.

The presence of one-bank holding companies makes this situation ripe for change. If a one-bank holding company acquires a subsidiary engaged in commerce while at the same time it holds indirectly, through its bank subsidiary, stock of another corporation also engaged in the same line of commerce, the acquisition can surely be challenged if "the effect of such acquisition may be substantially to lessen competition, or to tend to create a monopoly."134 To make enforcement meaningful, the holding company must be required to disclose the aggregate percentage of stock held in the trust department of its bank subsidiary. Such disclosure could be made by periodic reports, a requirement which is incorporated in one of the current legislative proposals dealing with one-bank holding companies. ${ }^{135}$

\section{Monetary Policy}

One final problem that arises from the existence of the one-bank holding company structure is that it permits the banks to circumvent the Federal Reserve's monetary policy decisions. The Federal Reserve is authorized to establish maximum rates of interest which may be paid by member banks upon time deposits. ${ }^{130}$ If the Federal Reserve wishes to engage in a restrictive monetary policy to combat inflation, it sets a rate which is low relative to other interest-bearing investments.

With low interest ceilings, banks find it difficult to attract time deposits which serve as the basis for their loans. ${ }^{137}$ Banks are effectively restrained by Federal Reserve regulation from selling commercial paper in order to raise additional funds. ${ }^{138} \mathrm{~A}$ bank holding company, however,

133 "This section shall not apply to corporations purchasing such stock solely for investment and not using the same by voting or otherwise to bring about, or in attempting to bring about, the substantial lessening of competition." 15 U.S.C. $\$ 18$ (1964).

134 Id.

135 H.R. 6778, 91st Cong., 1st Sess. (1969), introduced by Congressman Wright Patman (D-Tex.), Chairman of the House Committee on Banking and Currency, contains the following amendment to the Federal Deposit Insurance Corporation Act: "Any insured bank which holds any securities in a fiduciary capacity at the end of any calendar quarter shall, not later than thirty days thereafter, file a statement with the Securities and Exchange Commission setting forth the descriptions and amounts of the securities so held." Id. $\$ 1(\mathfrak{f})$.

13612 C.F.R. § 217.3 (1969). Since 1936, maximum rates that may be paid by banks insured by the FDIC but not members of the Federal Reserve System have been the same as those established by the Board of Governors of the Federal Reserve System.

137 See BusInEss WEEK, April 5, 1969, at 98.

138 With certain specified exceptions, any promissory note issued by a member bank principally as a means of obtaining funds to be used in its banking business is defined by Federal Reserve Regulation $Q$ as a "deposit." 12 C.F.R. § 217.1(f) (1969). Bank-issued 
is not so restricted. ${ }^{139}$ The holding company may sell its own commercial paper at whatever interest rate supply and demand in the money market establishes, an interest rate which undoubtedly would be higher than banks could pay on time deposits.

The proceeds from the holding company's sale of commercial paper may then be used to purchase loans from its subsidiary bank. The bank in turn could use the money so acquired to make additional loans much to the chagrin of the Federal Reserve. This practice is already in operation in a few one-bank holding companies. ${ }^{140}$

If the one-bank holding companies were permitted to enter any business area they desired, then circumvention of the Federal Reserve's monetary policy would probably not occur to any significant extent. The reason is that the holding company was formed in order to permit investment in areas yielding a higher rate of return than can be obtained by lending the funds. It would be defeating the very purpose of establishing a holding company if it were used merely to obtain additional loanable funds for the bank.

\section{CONCLUSION}

The reasons for opposition to one-bank holding companies are as varied as the groups advancing them. Some persons fear size as such. Others have lived through the Great Depression and fear banks as such. Still others seek to avoid competing with banks which may turn out to be more efficient than they are. Then there are those who fear takeover attempts and see bank holding companies as an additional source of takeover potential. Many persons believe that one-bank holding companies would erode well-established principles designed to enhance depositor safety or would lead to a lessening of competition.

But all of these fears and beliefs are held together by a common factor: they lack both historical and theoretical support. To be sure, the one-bank holding company structure may pose some problems

commercial paper would consequently be subject to the limitation on interest imposed by Regulation $Q$. At present, the maximum interest which may be paid is $61 / 4 \%$ per annum for a single maturity time deposit of $\$ 100,000$ or more. 12 C.F.R. $\$ 217.6$ (a) (1969). It is not likely that a bank would be able to sell its commercial paper in a money market yielding substantially higher rates of return for alternative forms of investment. Thus, by maintaining an interest ceiling lower than the existing rates in the money market, the Federal Reserve can effectively prohibit banks from issuing commercial paper.

139 The Federal Reserve Board has indicated that it is considering imposing a reserve requirement on the commercial paper issued by one-bank holding companies although the legality of such action is admittedly uncertain. Wall Street Journal, July 1, 1969, at 2 , col. 3 .

140 The volume of commercial paper issued by one-bank holding companies is believed to be considerably less than $\$ 1$ billion. Wall Street Journal, July 1, 1969, at 2, col. 3. See also BuSINESS WEEK, April 5, 1969, at 98. 
that need to be corrected through legislative action. But arguments over what activities the holding companies should be permitted to engage in; arguments over which agency should make the decision; and arguments as to how far back proposed "grandfather clauses" should go, all appear quite inappropriate to the consideration of the real problems engendered by or exacerbated through the existence of one-bank holding companies. 